J. Perinat. Med. 16 (1988) 31

\section{Pulsatile oxytocin for induction of labor: a randomized prospective controlled study}

\author{
Randall R. Odem ${ }^{1}$, Bruce A. Work ${ }^{2}$, jr., and M. Yusoff Dawood ${ }^{3}$ \\ ${ }^{1}$ Department of Obstetrics and Gynecology, Washington University School of \\ Medicine, St. Louis, Missouri, U.S.A. \\ ${ }^{2}$ Department of Obstetrics and Gynecology, University of Minnesota, Minneapolis, \\ Minnesota, U.S.A. \\ ${ }^{3}$ Department of Obstetrics and Gynecology, University of Illinois College of \\ Medicine, Chicago, Illinois, U.S.A.
}

\section{Introduction}

In 1927, HoFBAUER AND HoERNER [11] used posterior pituitary extracts to induce labor. Since then, oxytocin has been synthetically prepared and widely used for both induction and augmentation of labor [3]. More recently oxytocin has been employed for the oxytocin challenge test to evaluate fetal heart response to the stress of uterine contractions. Oxytocin has been given transbucally, intramuscularly or intravenously but in all its uses, it is generally given intravenously through a continuous infusion. The transbuccal route has been largely abandoned and the intramuscular route is only used in veterinary practice [3]. With careful intrauterine pressure monitoring and continuous fetal heart rate surveillance, oxytocin is quite safe and well accepted but there are several side effects, all of which appear to be dose-dependent.

Since oxytocin is secreted episodically in spurts or pulses [7] and myometrial oxytocin receptor sites while occupied are unavailable, continuous intravenous infusion of oxytocin does not appear to be consistent with physiological principles of endogenous oxytocin release in vivo. Administration of oxytocin in pulsatile boluses is more consistent with the physiologic release of this neurohypophyseal hormone and its effect on the myometrium. The total dose of oxytocin required could be reduced. In a preliminary study, PAvLou et al. [12] obtained encouraging results which showed that pulsed administration of oxytocin was just as ef-

\section{Curriculum vitae}

RANDALL ODEM received his bachelor and medical degrees from the University of Iowa. He then completed four years residency training in Obstetrics and Gynecology at the University of Illinois in Chicago. Since that time, he has been undergoing subspecialty training in Reproductive Endocrinology and

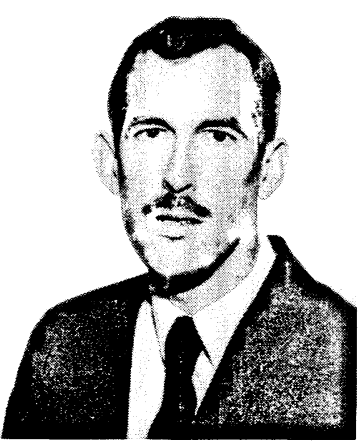

Infertility at Washington University School of Medicine in St. Louis. His current research interests are focused on sperm biochemistry.

fective as continuous intravenous infusion for induction of labor. A prospective, randomized study was initiated to compare the efficacy and safety of pulsed administration of oxytocin with the traditional continuous intravenous infusion method for induction of labor. This paper reports our findings of such a study.

\section{Materials and methods}

\subsection{Patient selection}

Twenty pregnant patients in the third trimester with medical indications for induction of labor and who signed an informed consent were selected 
for this prospective randomized study, which was aprroved by our Institutional Review Board. The decision to induce labor was made by the obstetrical staff managing the patient and did not involve the study investigators. Women with a previous uterine scar, a non-cephalic fetal presentation or a clinically contracted pelvis were excluded. Patients were randomized into the treatment group by their medical record number. A pelvic examination was performed to assess the Bishop score [1]. One of us (RRO) examined all the patients for the Bishop score, monitored them throughout their induction and was with them throughout their oxytocin administration. Once the cervix was 2 centimeters dilated, amniotomy was performed. All patients were monitored continuously for uterine contractions and fetal heart by external methods and after amniotomy, with internal uterine pressure catheter and fetal scalp electrode. The fetal monitoring and uterine pressure tracings throughout the induction until delivery were reviewed. Ten patients received oxytocin by pulsatile intravenous administration while the other 10 received oxytocin by continuous intravenous infusion.

\subsection{Adminstration of oxytocin}

Oxytocin was delivered in pulsatile boluses every 8 minutes via an intermittent infusion pump model As-2C (Autosyringe, Hooksett, New Hampshire). Each bolus was delivered over a tensecond period. The oxytocin was made up in 2 different concentrations (10 Units of oxytocin in $100 \mathrm{ml}$ of normal saline or 40 Units of oxytocin in $50 \mathrm{ml}$ of normal saline) to provide a wide range of dose per pulse as well as ease of administration. Pulsed administration of oxytocin was initially started at $1 \mathrm{mU} /$ pulse every 8 minutes with the pulsed dose doubled every 24 minutes (interval of 3 pulses of the same dose) until the patient was in adequate labor which is establishment of regular contractions equal to or greater than 160 Montevideo units. When the pulsed dose reached $32 \mathrm{mU} /$ pulse, the higher concentration of oxytocin solution (40 Units in $50 \mathrm{ml}$ of normal saline) was used.

The control group received continuous intravenous infusion of oxytocin administered by an IMED 927 pump (Imed Corporation, San Diego, California). Oxytocin infusion was started at $1 \mathrm{mU} /$ minute and doubled every 30 minutes until $8 \mathrm{mU} /$ minute, after which it was increased by $4 \mathrm{mU} /$ minute every 30 minutes until uterine con- tractions similar to that described for the pulsed oxytocin group were established.

The clinical management of the two groups was similar with respect to volume of fluids administered, monitoring techniques and care by the same team of labor and delivery physicians with one of us (PRO) present throughout the induction. The patients in the two groups were subsequently compared and analyzed for their obstetrical histories, labor and delivery outcome, neonate profile and oxytocin data.

\subsection{Statistical analysis}

The means \pm stardard error of the means were analyzed for differences using the non-paried students' $t$ test, chi-square analysis and one-way analysis of variance. Two-tailed $p$ values were employed and values greater than 0.05 were considered not dignificant.

\section{Results}

The patient profiles in the pulsed and control groups are summarized in table I. There were no significant differences between the two groups. Both groups had many obese individuals. Bishop scores of the cervix were similar in both groups. In the pulsed oxytocin group, 2 patients had Bishop scores of 4 or less while 8 had Bishop scores of more than 4 . In the continuous group, 3 patients had Bishop scores of 4 or less while 7 had Bishop scores of more than 4.

Table II summarizes the events during labor and delivery. The time intervals were calculated from the onset of oxytocin administration. The cesarean section rates were high in both groups. In each group there was a cesarean section performed for fetal distress and one for uterine hypotonia. Two patients in the pulsed group and 3 patients in the continuous group were delivered abdominally for failure to progress. These patients failed to progress at the same cervical dilatation $(5 \mathrm{~cm}$ or more) with no further descent of the presenting part for more than 3 hours. Of these 5 patients, 2 (one from each treatment group) had large babies (4220 and 4530 grams), one had chorioamnionitis and 2 (one from each treatment group) which had been at 6-7 cm dilatation for a prolonged time had babies weighing 3620 and 3390 grams. Primigravid patients had a higher cesarean section rate, but the number of patients is not large enough 
Table I. Clinical profile of patients undergoing induction of labor with either pulsed or continuous intravenous administration of oxytocin.

\begin{tabular}{llll}
\hline Maternal characteristics & $\begin{array}{l}\text { Pulsed } \\
\text { oxytocin group } \\
\mathrm{n}=10\end{array}$ & $\begin{array}{l}\text { Continuous } \\
\text { oxytocin group } \\
\mathrm{n}=10\end{array}$ & $\begin{array}{l}\text { Differences between } \\
\text { pulsed and continuous } \\
\text { oxytocin groups }\end{array}$ \\
\hline Age (years) & $\begin{array}{l}23.5 \pm 1.8^{*} \\
(17-30) \dagger\end{array}$ & $\begin{array}{l}25.2 \pm 2.0 \\
(18-38)\end{array}$ & $\mathrm{ns}$ \\
Parity & $\begin{array}{l}0.8 \pm 0.3 \\
(0-3)\end{array}$ & $\begin{array}{l}1.0 \pm 0.6 \\
(0-5)\end{array}$ & $\mathrm{ns}$ \\
Gestation (days) & $285 \pm 7.2$ & $283 \pm 5.8$ & $\mathrm{~ns}$ \\
Maternal weight $(\mathrm{kg})$ & $(261-301)$ & $(251-301)$ & \\
& $95.2 \pm 5.0$ & $97.1 \pm 7.3$ & $\mathrm{~ns}$ \\
Bishops score & $(78-113)$ & $(73-128)$ & \\
& $7.3 \pm 0.7$ & $5.9 \pm 0.9$ & $\mathrm{~ns}$ \\
\hline
\end{tabular}

ns $=$ not significant

$*=$ mean \pm S.E.M.

$\dagger=$ number in brackets indicate the range.

Table II. Labor and delivery data (mean \pm S.E.M.) of patients who had induced labor with either pulsed or continuous intravenous administration of oxytocin.

\begin{tabular}{llll}
\hline & $\begin{array}{l}\text { Pulsed } \\
\text { oxytocin group } \\
(\mathrm{n}=10)\end{array}$ & $\begin{array}{l}\text { Continuous } \\
\text { oxytocin group } \\
(\mathrm{n}=10)\end{array}$ & $\begin{array}{l}\text { Differences between } \\
\text { pulsed and continuous } \\
\text { oxytocin groups }\end{array}$ \\
\hline Time till adequate labor $(\mathrm{min})^{*}$ & $\begin{array}{l}241 \pm 34 \\
(120-424) \dagger\end{array}$ & $\begin{array}{l}270 \pm 51 \\
(70-505)\end{array}$ & $\mathrm{ns}$ \\
Induction-delivery internal (min) & $\begin{array}{l}648 \pm 127 \\
(82-1102)\end{array}$ & $\begin{array}{l}812 \pm 95 \\
(190-1173)\end{array}$ & $\mathrm{ns}$ \\
Incidence of hyperstimulation** & $10 \%$ & $60 \%$ & $\mathrm{~ns}$ \\
Vaginal delivery rate & $60 \%$ & $50 \%$ & $\mathrm{~ns}$ \\
Change in Hgb (g/dl) & $1.3 \pm 0.3$ & $1.5 \pm 0.27$ & $\mathrm{~ns}$ \\
& $(0.4-3.0)$ & $(0.3-2.7)$ & $\mathrm{ns}$ \\
Pain medications needed & $60 \%$ & $70 \%$ & $\mathrm{~ns}$ \\
\hline
\end{tabular}

* Adequate labor $=$ regular uterine contractions $\geq 160$ Montevideo units.

** Hyperstimulation defined as increased basal tone or frequency of uterine contraction that requires stopping oxytocin.

$\dagger$ Number in brackets indicate the range.

for statistical evaluation. Three out of 4 primigravidas in the control group and all 4 primigravidas in the pulsed group were delivered by cesarean section.
Table III summarizes the profile of the neonates. The mean birth weight was significantly higher in the pulsed oxytocin group ( $p=<0.05$ ). 
Table III. Profile of neonates born to mothers who underwent induction of labor with pulsed or continuous intravenous administration of oxytocin.

\begin{tabular}{|c|c|c|c|}
\hline Profile of neonate & $\begin{array}{l}\text { Pulsed } \\
\text { oxytocin group } \\
(\mathrm{n}=10)\end{array}$ & $\begin{array}{l}\text { Continuous } \\
\text { oxytocin group } \\
(\mathrm{n}=10)\end{array}$ & $\begin{array}{l}\text { Differences between } \\
\text { pulsed and continuous } \\
\text { oxytocin groups }\end{array}$ \\
\hline Sex (females) & $30 \%$ & $60 \%$ & ns \\
\hline Weight (g) & $\begin{array}{l}3876 \pm 162 \\
(3065-4530) \dagger\end{array}$ & $\begin{array}{l}3255 \pm 251 \\
(1720-4220)\end{array}$ & $\mathrm{p}=<0.05^{*}$ \\
\hline $\begin{array}{l}\text { Apgar score } \\
1 \text { minute }\end{array}$ & $\begin{array}{l}6.8 \pm 0.6 \\
(4-0)\end{array}$ & $\begin{array}{l}7.7 \pm 0.3 \\
(6-9)\end{array}$ & ns \\
\hline 5 minutes & $\begin{array}{l}8.6 \pm 0.17 \\
(8-9)\end{array}$ & $\begin{array}{l}8.7 \pm 0.3 \\
(7-9)\end{array}$ & ns \\
\hline
\end{tabular}

ns $=$ not significant

$*$ = significant

$\dagger=$ number in brackets indicate range

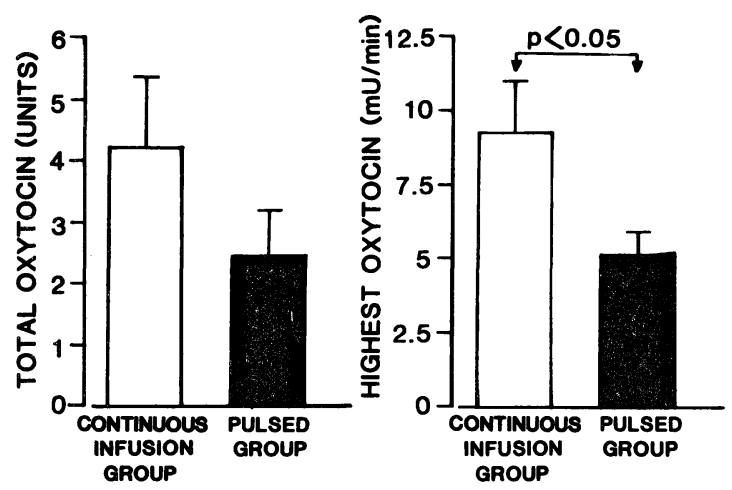

Figure 1. Mean \pm SEM (standard error of the mean) dose of oxytocin required for induction of labor with pulsed or continuous intravenous infusion of oxytocin. Pulsatile administration of oxytocin required less total dose of oxytocin and a significantly lower peak oxytocin infusion rate than continuous intravenous infusion $(p=$ $<0.05)$.

The amounts of oxytocin administered are shown in figure 1. With continuous oxytocin administration, the patients required $71 \%$ more oxytocin than with pulsed administration. When the highest dose of oxytocin used in each patient was calculated and transformed to $\mathrm{mU} / \mathrm{min}$, the pulsed oxytocin group received a significantly lower peak dose of oxytocin $(5.2 \pm 0.8)$ than the continuous oxytocin group $(9.2 \pm 1.8, \mathrm{p}=<0.05)$.

\section{Comments}

The present pilot study of a limited number of patients shows that pulsed oxytocin infusion is as effective and safe as continuous intravenous infusion of oxytocin for induction of labor but has the additional advantage of requiring much less oxytocin. Our findings support an earlier report demonstrating the efficacy of pulsed oxytocin infusion combined with amniotomy for induction of labor [12]. However, we have simplified our protocol in the present study where the oxytocin is given long before amniotomy and in the presence of a low Bishop score. Thus, induction of uterine contractions and subsequent establishment of labor can be readily and safely achieved with lower doses of oxytocin using pulsatile infusion of oxytocin.

Oxytocin is secreted episodically in spurts or pulses during pregnancy and labor in women [7, 10]. DAwood et al. [7] have shown that in normal human parturition, 2 to 3 pulses of oxytocin are released every 10 minutes. Most peptide hormones and even fetoplacental steroid hormones are increasingly shown to be secreted episodically.

Specific receptors for oxytocin are present in the uterine smooth muscle and the occupied receptors become temporarily unavailable to the infused or circulating oxytocin for binding. The duration of the oxytocin-receptor binding or receptor occupation is not known. Thus continuous intravenous infusion of oxytocin is inconsistent with our 
understanding of oxytocin secretion and our current concept of peptide hormone-receptor binding. Pulsatile administration of oxytocin mimicks episodic release of oxytocin during labor and could avoid continuous flooding of the uterus and saturation of unavailable, occupied receptor sites.

We have chosen an oxytocin pulse frequency of every eight minutes for convenience of adjusting the autosyringe pump and to balance between the frequency of oxytocin spurts seen during normal labor and the half-life of oxytocin. The half-life of oxytocin is 10 minutes [8] and the metabolic clearance rate is similar in the pregnant and nonpregnant states [4]. It is noteworthy that the highest dose of oxytocin infused per minute (expressed for comparison purposes) was significantly lower with pulsatile administration than with continuous infusion (figure 1). In this respect, it is striking that the mean maximum dose of oxytocin required by pulsatile infusion was 5.2 $\mathrm{mU} / \mathrm{min}$, a rate which is similar to human fetal oxytocin infusion of $3.0 \mathrm{mU} / \mathrm{min}$ towards the maternal compartment via the umbilical cord during spontaneous labor $[4,6]$. The maximum dose of oxytocin per minute required for pulsatile administration is also consistent with the physiolgoical dose of oxytocin so strongly advocated by some [14]. Furthermore, the lower dose of oxytocin and its pulsatile delivery are probably significant factors in the lower incidence of uterine hyperstimulation compared to continuous oxytocin infusion.

The total dose of oxytocin required for pulsed administration to induce adequate uterine contractions and establish labor was much smaller than that needed for continuous infusion. Such a reduction can be clinically important towards the likelihood of developing neonatal hyperbilirubinemia. The pathogenesis of oxytocin-induced neonatal hyperbilirubinemia is due to increased osmotic fragility of the erythrocytes and transplacental hyponatremia both of which are time-related and dose-dependent on oxytocin [2, 13]. A highly significant correlation between cord bilirubin levels and the total amount of oxytocin given to the mother to induce labor has been reported [9], with increased neonatal hyperbilirubinemia found when mothers were given a mean total oxytocin dose of $4500 \mathrm{mU}$ or more [2]. Thus, pulsed administration with a mean total oxytocin dose of $2454 \mathrm{mU}$ is less likely to give rise to oxytocin-induced neonatal hyperbilirubinemia than continuous intravenous infusion of oxytocin.
With a trend towards less hyperstimulation with pulsatile administration, this method of giving oxytocin offers an advantage over continuous administration. The reduced occurrence of uterine hyperstimulation with the pulsatile administration is likely to be due to the lower dose of oxytocin required since we have previously established that the uterine activity can be correlated to the maternal plasma oxytocin levels attained when oxytocin was infused into the mother [5].

There is also the added advantage of reduced cost with pulsatile administration of oxytocin. We have calculated that the average cost of medication and supplies in our institution for pulsatile administration of oxytocin is $\$ 66$ versus $\$ 102$ for continuous infusion.

The cesarean section rates for both methods of giving oxytocin were higher than our overall cesarean section of $22.4 \%$ for the same period of time. This is not altogether unexpected as the patients recruited into the study were undergoing induction of labor for significant medical reasons and were therefore at high risk for abdominal delivery. Inspite of the pulsatile oxytocin group having a significantly higher mean infant birth weight, the cesarean section rate was similar to that for the continuous oxytocin infusion group. The differences in the mean birth weight between the two groups were unlikely to have affected the differences observed in their response to their respective methods of induction in favor of the pulsed oxytocin group. Indeed if there were to be an effect, the significantly higher birth weight in the pulsed oxytocin group would have a less favorable effect on the response to induction. However, inspite of the larger birth weights, the pulsed oxytocin group gave more favorable results.

Overall, the findings in this prospective, randomized study of a limited number of patients indicate that pulsatile administration of oxytocin appears to be as effective as the conventional continuous intravenous infusion for induction of labor. Pulsatile administration of oxytocin is as safe and perhaps safer than continuous oxytocin infusion, with reduced incidence of uterine hyperstimulation, reduced total dose and infusion rate of oxytocin and reduced cost. Pulsatile administration of oxytocin is more consistent with physiological principles of the secretion of this neurohypophysial hormone.

Further studies on a larger number of patients should be a worthwhile endeavour. 


\begin{abstract}
Summary
In a prospective randomized study, 20 patients with term pregnancies underwent induction of labor with either continuous or pulsed (every 8 minutes) intravenous oxytocin infusion. There were no significant differences with respect to induction-labor interval, inductiondelivery interval, cesarean section rates, need for pain relief and Apgar scores. Sixty percent of patients receiving continuous oxytocin infusion developed uterine hyperstimulation but only $10 \%$ receiving pulsed oxytocin did so. However, the difference was not significant. The mean \pm SEM total amount of oxytocin given by continuous infusion was $4237 \pm 1066 \mathrm{mU}$ which was
\end{abstract}

$70 \%$ more than by pulsatile infusion $(2454 \pm 808 \mathrm{mU})$. The highest rate of oxytocin infused was significantly lower by pulsatile administration $(5.2 \pm 0.8 \mathrm{mU} / \mathrm{min})$ than by continuous infusion $(9.2 \pm 1.8 \mathrm{mU} / \mathrm{min}$, $\mathrm{p}=<0.05$ ).

Our study demonstrates that pulsed administration of oxytocin every 8 minutes is as effective and safe as continuous intravenous infusion of oxytocin for induction of labor, requires less oxytocin with therefore, a wider margin of safety and is consistent with the pulsatile release of oxytocin during normal labor.

Keywords: Induction of labor, oxytocin, pulsatile oxytocin.

\section{Zusammenfassung}

Intermittierende Gabe von Oxytozin zur Einleitung der Wehen: eine randomisierte kontrollierte Studie

In einer randomisierten prospektiven Studie unterzogen sich 20 Patientinnen mit ausgetragenen Schwangerschaften einer Weheneinleitung entweder mit kontinuierlicher oder pulsatiler (alle 8 Minuten) i. v. Infusion von Oxytozin. Es gab keine nennenswerten Unterschiede, weder hinsichtlich des Einleitungs-Wehenintervalls, des Einleitungs-Geburtsintervalls, der Frequenz an Kaiserschnitten und des Bedarfs an Schmerzmitteln noch des Apgar-Schemas. $60 \%$ der Patientinnen, die eine Dauerinfusion erhalten hatten, zeigten eine uterine Hyperstimulation, welche aber nur zu $10 \%$ bei Frauen mit einer intermittierten Infusion auftrat. Nichtsdestoweniger war der Unterschied nicht signifikant. Die mittlere
Gesamtkonzentration \pm SEM, von Oxytozin mittels Dauerinfusion war $4237 \pm 1066 \mathrm{mU}$. Dies war $70 \%$ mehr als mit intermittierender Infusion $(2454 \pm 808$ $\mathrm{mU})$. Die höchste Dosis an infundiertem Oxytozin war bei der intermittierenden Methode $(5,2 \pm 0,8 \mathrm{mU} / \mathrm{min})$ deutlich niedriger als bei der Dauerinfusion $(9,2 \pm 1,8$ $\mathrm{mU} / \mathrm{min}, \mathrm{p}=<0.05$ ).

Unsere Studie zeigt, daß die intermittierende Gabe von Oxytozin alle 8 Minuten genauso effektiv und sicher ist wie die Dauerinfusion von Oxytozin zur Weheneinleitung, da $\beta$ aber weniger Oxytozin gebraucht wird und damit ein größerer Sicherheitsbereich gegeben ist. Außerdem stimmt diese Applikationsart mit der intermittierten Freigabe von Oxytozin während nicht medikamentös induzierter Wehen überein.

Schlüsselwörter: Einleitung von Wehen, Oxytozin, pulsatile Oxytozingabe.

\section{Résumé}

Déclenchement du travail par ocytocine pulsatile: étude randomisée prospective et controlée

Dans une étude randomisée prospective, 20 patients à terme ont eu un déclenchement de l'accouchement soit par une perfusion continue d'ocytocine soit par une perfusion pulsatile (toutes les 8 minutes). Il n'y a pas eu de différence significative en ce qui concerne l'intervalle induction-travail, l'intervalle induction-accouchement, le taux de césarienne, la nécessité de soulager la douleur ni les scores d'Apgar. Soixante pour cent des patientes ayant une perfusion continue d'ocytocine ont présenté une hyperstimulation mais seulement $10 \%$ de celles ayant eu une perfusion pulsatile. Toutefois la différence n'est pas significative. La quantité moyenne totale d'ocy- tocine utilisée par perfusion continue a été de $4237 \pm$ $1066 \mathrm{mU}$, ce qui est $70 \%$ en plus que pour les perfusions pulsatiles $(2454 \pm 808 \mathrm{mU})$. Le rythme le plus élevé d'administration d'ocytocine est significativement inferieur pour les perfusions pulsatiles $(5,2 \pm 0,8 \mathrm{mU} / \mathrm{min})$ que pour les perfusions continues $(9,2 \pm 1,8 \mathrm{mU} / \mathrm{min}$, $\mathrm{p}<0,05)$.

Notre étude démontre que l'administration pulsatile d'ocytocine toutes les 8 minutes est aussi efficace et aussi sure que la perfusion continue d'ocytocine en intraveineux pour déclencher le travail qu'elle nécellite moins d'ocytocine avec cependant une marge de sureté plus large et qu'elle est dans la logique de la libération pulsatile d'ocytocine au cours du travail normal.

Mots-clés: Déclenchement du travail, ocytocine, ocytocine pulsatile.

Acknowledgements: We thank Mr. STEPHEN SAGON of Autosyringe, Hooksett, New Hampshire for the loan of the Autosyringe model AS-2C pumps used in this study. The assistance and cooperation of the labor and delivery staff and the pharmacy staff are deeply appreciated. 


\section{References}

[1] Bishop E: Pelvic scoring for elective induction. Obstet Gynecol 24 (1964) 266

[2] BuCHAN P: Pathogenesis of neonatal hyperbilirubinaemia after induction of labor with oxytocin. $\mathrm{Br}$ Med J 2 (1979) 1255

[3] Dawoon MY: Induction of labor. In: Amico JA, AG RoBINSON: Oxytocin: Clinical and Laboratory Studies. Elsevier Science Publishers B. V., Amsterdam 1985

[4] Dawood MY: Neurohypophyseal hormones. In: FUCHS F, A KLOPPER: Endocrinology of Pregnancy, Third Edition. Harper and Row, Philadelphia 1983

[5] Dawood MY, NH Lauersen, D Trivedi, O YliKORKALA, F Fuchs: Studies on oxytocin in the baboon during pregnancy and delivery. Acta Endocrinol 91 (1979) 704

[6] Dawood MY, CF WaNG, R GuPTA, F Fuchs: Fetal contribution to oxytocin in human parturition. Obstet Gynecol 52 (1978) 205

[7] Dawood MY, O Ylikorkala, D Trivedi, F Fuchs: Oxytocin in maternal circulation and amniotic fluid during pregnancy. J Clin Endocrinol Metab 49 (1979) 429

[8] Dawood MY, O Ylikorkala, D Trivedi, F Fuchs: Oxytocin levels and disappearance rate and plasma follicle-stimulating hormone and luteinizing hormone after oxytocin infusion in man. J Clin Endocrinol Metab 50 (1980) 397
[9] D'Souza SW, P Black, T MacFarlane, B RICHARDS: The effect of oxytocin in induced labor on neonatal jaundice. Br J Obstet Gynaecol 86 (1979) 133

[10] GibBens GLD, T ChaRD: Observations on maternal oxytocin release during human labor and the effect of intravenous alcohol administration. Am J Obstet Gynecol 126 (1976) 243

[11] Hofbauer J, JK HoERner: The nasal application of pituitary extract for the induction of labor. Am J Obstet Gynecol 14 (1927) 137

[12] Pavlou C, GH Barker, A Roberts, GVP ChamBERLAIN: Pulsed oxytocin infusion in the induction of labour. Br J Obstet Gynaecol 85 (1978) 96

[13] SINGHI S, M SINGH: Pathogenesis of oxytocin-induced neonatal hyperbilirubinaemia. Arch Dis Child 54 (1979) 400

[14] TOAFF MD, J HEXRONI, R TOAFF: Induction of labor by pharmacological and physiological doses of intravenous oxytocin. Br J Obstet Gynaecol 85 (1978) 101

Received August 18, 1986. Revised December 10, 1986. Accepted December 13, 1986.

M. Yusoff Dawood, M. D.

Department of Obstetrics and Gynecology University of Illinois College of Medicine 840 South Wood Street Chicago, Illinois 60612, U.S. A. 